\title{
GOLD COAST UNIVERSITY COLLEGE
}

SIR,-May I, through your columns, appeal for help for the University College of the Gold Coast?

The Geology Department of this College is experiencing considerable difficulty in building up a teaching collection of fossils. There are few fossiliferous deposits in the Gold Coast itself and our collections must be built up from other countries. I am sure every long-established teaching department has a few spare fossils which it would be willing to part with for this purpose. Departments at home cannot, of course, fully realize the difficulties of starting from scratch. In the case of rocks and minerals fairly adequate collections can be bought, but it is more difficult in the case of fossils. It would, therefore, be a very great help, indeed, if other departments or individual geologists could send us some of their spare material, or if they could see their way to collect some for us during class excursions. This department would defray the costs of postage, or freight, and it would be best to send very small parcels by air. Packages by sea seldom reach us in less than six months and often take longer, so that it would be of the greatest help if anything available could be offered soon in order to reach us by the beginning of the new session in October. Packages addressed to The Bursar (for Geology) usually escape Customs· formalities.

\section{Geology Department,}

William J. McCallien.

UNIVERSITY COLLEGE OF THE GOLD COAST, Achimota, Gold Coast, West Africa.

\section{SPECIES AND SUBSPECIES}

Sir,-Mr. McKerrow (Geol. Mag., lxxxix, 148-150) and I (Geol. Mag., lxxxviii, 88-102) disagree not in our appreciation of the phenomena but in their nomenclatural treatment. Mr. McKerrow prefers to call a morphological "species" what I regard as a morphological "variety". I feel unhappy if I am asked to call by different specific names individuals from a single horizon which may be regarded as part of a single interbreeding "plexus"; but Mr. McKerrow is as entitled to his opinion as I to mine, and certainly many palaeontologists would side with him and against me.

Mr. McKerrow has, however, misunderstood my intention in proposing quantitative limits to the range of a chronological subspecies. The fault is, I $\mathrm{am}$ afraid, mine, for others have misunderstood me in the same way. I intended to suggest that a chronological subspecies was an arbitrary length of lineage. If two populations, being members of such a lineage, are drawn from different horizons, and, on statistical analysis, their means are found to differ by more than $4 \sigma$ in any character, they may be regarded as specifically distinct. If the difference is less than $4 \sigma$, they may be regarded as subspecifically distinct, but only if such distinction is both statistically significant and of stratigraphical value. It seems to me pointless to give distinct names to populations which, though statistically different, have no stratigraphical significance. Many very small topodemes of living animals, when statistically examined, are found to differ significantly (e.g. Peromyscus in North America ; Cepaea in this country). Nobody would suggest evaluating such "family" groups as geographical subspecies.

Mr. Mckerrow accuses me of giving an incorrect definition of a geographical subspecies; I did not give any definition at all.

\section{Department of Geology, \\ THE UNIVERSITY, \\ St. George's Square, SHEFFIELD 1.}

28th April, 1952.

\section{P. C. Sylvester-Bradley.}

